\title{
Newly Collected Specimens of the Sleeper Eleotris acanthopoma (Teleostei: Eleotridae) from French Polynesia Indicate a Wide and Panmictic Distribution in the West and South Pacific ${ }^{1}$
}

\author{
Ken Maeda, ${ }^{2,3,4}$ Takabiko Mukai, ${ }^{5}$ and Katsunori Tacbibara ${ }^{2}$
}

\begin{abstract}
The morphology of Eleotris acanthopoma collected from Moorea in French Polynesia is described. This is the first record of this species from French Polynesia, greatly expanding the known range, which was previously only considered to extend from southern Japan to New Caledonia. Nucleotide sequences of the mitochondrial ND5 gene of several Eleotris species and related genera indicate that E. acanthopoma from Moorea belongs to the same lineage as E. acanthopoma from Japan and the Philippines. Despite being separated by a distance of approximately $10,000 \mathrm{~km}$, two of the specimens from Moorea and one from the Philippines had identical nucleotide sequences. Results of this study indicate that extensive dispersal occurs during the pelagic larval stage of this species.
\end{abstract}

Fishes of THE genus Eleotris have a global distribution, primarily inhabiting estuaries and freshwater streams of tropical and subtropical regions (Pezold and Cage 2002). In all of the species studied to date, newly hatched larvae are very small and undeveloped (Lindstrom 1999, Dotsu et al. 2004, Maeda et al. 2008) and spend a relatively long time as pelagic larvae ( $2-5.5$ months) before becoming established in their adult habitats (Bell et al. 1995, Maeda and Tachihara 2005, Maeda et al. 2007). During this pelagic stage, the larvae are often transported considerable

\footnotetext{
${ }^{1}$ This study was partially supported by the 21 st Century Center of Excellence (COE) program of the University of the Ryukyus. Manuscript accepted 4 July 2010.

${ }^{2}$ Laboratory of Fisheries Biology and Coral Reef Studies, Faculty of Science, University of the Ryukyus, 1 Senbaru, Nishihara-cho, Nakagami-gun, Okinawa 903-0213, Japan.

${ }^{3}$ Marine Genomics Unit, Okinawa Institute of Science and Technology Promotion Corporation, 1919-1 Tancha, Onna-Son, Kunigami-gun, Okinawa 904-0412, Japan.

${ }^{4}$ Corresponding author (e-mail: goby@live.jp).

${ }^{5}$ Faculty of Regional Studies, Gifu University, 1-1 Yanagido, Gifu-shi, Gifu 501-1193, Japan.
}

Pacific Science (2011), vol. 65, no. 2:257-264

doi: $10.2984 / 65.2 .257$

(C) 2011 by University of Hawai'i Press

All rights reserved distances from their natal habitats (Maeda et al. 2007). Consequently, several Eleotris species have been reported to have extensive geographical distributions. In particular, Eleotris fusca may be the most widely distributed amphidromous fish, with a range extending from South Africa to Japan and French Polynesia (Pusey et al. 2004). However, because the taxonomy of this genus has not yet been sufficiently clarified, determining species distribution ranges is difficult. It is therefore necessary to accurately identify and record all occurrences of Eleotris species to increase our understanding of their distribution.

Although E. fusca has been recorded on most of the mountainous islands in the Marquesas, Austral, Gambier, and Society islands (Fowler 1932, Herre 1931, 1932, Marquet and Galzin 1992, Resh et al. 1999, Englund 2003, 2004), other Eleotris species have not yet been reported in French Polynesia. However, here we describe the morphologies of five Eleotris acanthopoma specimens collected on Moorea and in so doing establish a record of this species in French Polynesia. To discuss the phylogeography of this species, nucleotide sequences of the mitochondrial ND5 gene of these specimens were compared with those of other Eleotris species, including $E$. acanthopoma and related genera mainly from the Northwest Pacific. 


\section{MATERIALS AND METHODS}

Five Eleotris acanthopoma specimens (URM-P 45009-45013; 25.3-45.7 mm SL; three adult males, one adult female, and one juvenile) were collected on the coast of Papetoai, Moorea, French Polynesia (17 ${ }^{\circ} 9^{\prime}$ S, $149^{\circ} 52^{\prime}$ $W$ ) on 4 December 2006 by K.M. with a hand net. Tissue samples obtained from the right pectoral fins of four of the five specimens were fixed in $99 \%$ ethyl alcohol for DNA analysis. Specimens, including the fish not used for tissue samples, were fixed in 10\% formalin and preserved in 70\% ethyl alcohol for morphological analysis.

Morphological features were described following the methods given in Nakabo (2002), with the following exceptions: scale counts followed Akihito (1967), notation for the pattern of interdigitation of the dorsal fin pterygiophores between the neural spines $(\mathrm{P}-\mathrm{V})$ followed Akihito (1984), and body depth was measured at the base of the pectoral fin and at the origin of the anal fin. Measurements were taken from the left side using a dial caliper and micrometer to the nearest $0.1 \mathrm{~mm}$. The number of vertebrae was counted from radiographs. Cephalic sensory papillae were observed by staining the specimens with cyanine blue.

Total genomic DNA of four E. acanthopoma specimens was extracted from the right pectoral fin samples. DNA extraction, gene amplification, and sequencing of a part of the mitochondrial NADH dehydrogenase subunit 5 (ND5) gene (ca. $1 \mathrm{kbp}$ ) were performed following the methods in Mukai et al. (2005). The nucleotide sequences obtained were compared with the same gene region in $E$. acanthopoma specimens collected in Japan $(n=7)$ and the Philippines $(n=2) ; E$. fusca collected in Japan $(n=3)$, the Philippines $(n=11)$, and Moorea, French Polynesia $(n=1)$; Eleotris melanosoma collected in Japan $(n=1)$; Eleotris oxycephala collected in Japan $(n=2)$; Bunaka gyrinoides collected in Japan $(n=2)$; and Belobranchus belobranchus collected in the Philippines $(n=1)$. The nucleotide sequences of these species were obtained using the same protocols as those used to analyze the French Polynesian E. acanthopoma samples, and all of the sequences were deposited in the GenBank/EMBL/DDBJ databases. In addition, a published nucleotide sequence of E. acanthopoma collected from Wakayama Prefecture, Japan (GenBank/EMBL/DDBJ accession number: AP004455 [Miya et al. 2003]) was also used for the analysis. The catalog numbers of the voucher specimens and accession numbers of the nucleotide sequences are provided in the Appendix.

\section{RESULTS}

\section{Morphological Description}

A photograph of Eleotris acanthopoma is shown in Figure 1. Dorsal fin rays VI-I,8; anal fin rays I,8; pectoral fin rays 16; pelvic fin rays I, 5 ; caudal fin rays $\mathrm{i}+13+\mathrm{i}(n=3)$ or $\mathrm{i}+14$ $(n=2)$; vertebrae $10+15=25 \quad(n=4)$ or $10+16=26(n=1) ; \mathrm{P}-\mathrm{V} 3 / \mathrm{I} \mathrm{II} \mathrm{II} \mathrm{I/8.}$

Scales in longitudinal row 50-54; scales in transverse row 13-15; scales in transverse series in the caudal peduncle 11-13. Ctenoid scales covering the lateral sides of the trunk

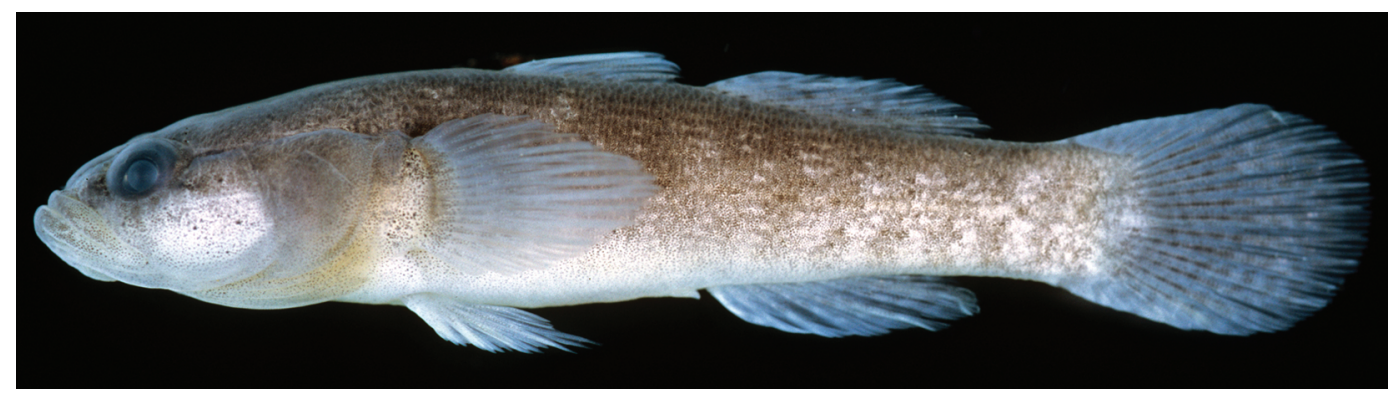

Figure 1. Eleotris acanthopoma (URM-P 45009, female, $45.3 \mathrm{~mm}$ in standard length) collected at Papetoai, Moorea, French Polynesia, on 4 December 2006. 
TABLE 1

Morphometric Measurements of Eleotris acanthopoma Collected in Moorea, French Polynesia

\begin{tabular}{|c|c|c|}
\hline Parameter & Adults & Juvenile \\
\hline $\begin{array}{l}\text { Number of specimens } \\
\text { examined }\end{array}$ & 4 & 1 \\
\hline Standard length $(\mathrm{mm})$ & $33.3-45.7$ & 25.3 \\
\hline Total length (mm) & $42.5-58.3$ & 32.7 \\
\hline \multicolumn{3}{|l|}{ In $\%$ of standard length } \\
\hline $\begin{array}{l}\text { Body depth at pectoral-fin } \\
\text { base }\end{array}$ & $18.6-20.8$ & 17.8 \\
\hline Body depth at anal-fin origin & $18.0-19.4$ & 15.8 \\
\hline Head length & $34.5-39.1$ & 35.2 \\
\hline Snout length & $8.1-11.0$ & 9.5 \\
\hline Eye diameter & $7.2-8.0$ & 7.9 \\
\hline Postorbital length of head & $19.8-21.8$ & 20.6 \\
\hline Upper jaw length & $11.7-13.8$ & 13.0 \\
\hline Length of caudal peduncle & $25.2-27.6$ & 25.3 \\
\hline Depth of caudal peduncle & $12.9-13.5$ & 11.9 \\
\hline Predorsal length & $41.0-43.8$ & 43.5 \\
\hline Pre second dorsal-fin length & $59.5-62.5$ & 61.7 \\
\hline Preanal length & $53.5-60.0$ & 55.7 \\
\hline $\begin{array}{l}\text { Length of first dorsal-fin } \\
\text { base }\end{array}$ & $15.5-17.7$ & 16.6 \\
\hline $\begin{array}{l}\text { Length of longest first } \\
\text { dorsal-fin ray }\end{array}$ & $13.2-15.0$ & 15.4 \\
\hline $\begin{array}{l}\text { Length of second dorsal-fin } \\
\text { base }\end{array}$ & $14.5-16.4$ & 15.8 \\
\hline $\begin{array}{l}\text { Length of longest second } \\
\text { dorsal-fin ray }\end{array}$ & $15.9-17.3$ & 16.6 \\
\hline Length of anal-fin base & $14.6-15.5$ & 13.8 \\
\hline $\begin{array}{l}\text { Length of longest anal-fin } \\
\text { ray }\end{array}$ & $15.9-17.1$ & 16.5 \\
\hline Length of pectoral-fin base & $9.3-9.9$ & 8.7 \\
\hline Length of pectoral fin & $24.9-27.0$ & 22.5 \\
\hline $\begin{array}{l}\text { Length of longest pectoral- } \\
\text { fin ray }\end{array}$ & $23.8-25.2$ & 22.1 \\
\hline Length of pelvic fin & $18.6-22.1$ & 22.5 \\
\hline
\end{tabular}

and almost the entire tail. Cycloid scales covering the dorsal trunk and head extending anteriorly to the interorbital area, upper opercle, belly, thorax, pectoral-fin base, and caudal-fin base.

Morphometric measurements are given in Table 1. Body elongate and cylindrical anteriorly and somewhat compressed posteriorly. Head somewhat depressed. Anterior nostril tubular; posterior nostril not tubular. Mouth oblique. Upper jaw extending below middle of pupil. Tip of lower jaw preceding tip of upper jaw. Anterior end of gill opening aligned vertically with the posterior margin of the preopercle. Second dorsal fin slightly higher than first dorsal fin, and of nearly equal height as the anal fin. Posterior end of first dorsal fin base separate or nearly touching second dorsal fin origin. Spines of first dorsal fin not elongated. First dorsal fin, 2nd, 3rd, or 4th spines longest. Anal fin origin aligned vertically with the base of 1 st or 2 nd soft rays of second dorsal fin. Posterior end of anal fin base aligned vertically with the base of 7 th or 8 th soft rays of second dorsal fin. All soft rays of second dorsal fin and anal fin branched; second dorsal fin, 4th, 5th, or 6th soft rays longest; anal fin, 5th or 6th soft rays longest. Posterior tips of second dorsal fin and anal fin extending to middle of caudal peduncle when depressed. All pectoral fin rays branched, except for uppermost 1 and lowermost $0-1$ rays. Pectoral fin without free ray, slightly exceeding posteriorly to vertical of base of 6th spine of first dorsal fin. Pelvic fin separated without frenum; all segmented rays of pelvic fin branched; 4th segmented ray longest. Caudal fin rounded; all segmented rays of caudal fin branched, except for uppermost 1 and lowermost $0-1$ rays.

Urogenital papilla of adult specimens exhibiting sexual dimorphism, slender in male and broad and rounded in female.

Patterns of cephalic sensory systems are shown in Figure 2. Head lacking canal and canal pore. Posterior ends of two longitudinal rows of sensory papillae on opercle well separated from each other; infraocular area with five transverse rows of sensory papillae, 2nd and 4th of which extended beyond longitudinal infraocular row, $3 \mathrm{rd}$ of which just attached to the longitudinal row; lower margin of preopercle with five transverse rows of sensory papillae.

Color in preservation: Dorsal and dorsolateral sides of body and head dark brown; ventral and ventrolateral sides of body and head creamy white background. Ventrolateral side of tail with six obscure dark brown transverse bands. Rather dark patches at 3, 4, 5, and 9 o'clock around eye and both upper and lower parts of pectoral-fin base. First dorsal fin translucent with dark brown proximal area and a longitudinal bar across middle part of fin; second dorsal fin translucent with dark brown proximal area and three to seven longitudinal bars; anal fin grayish brown without 


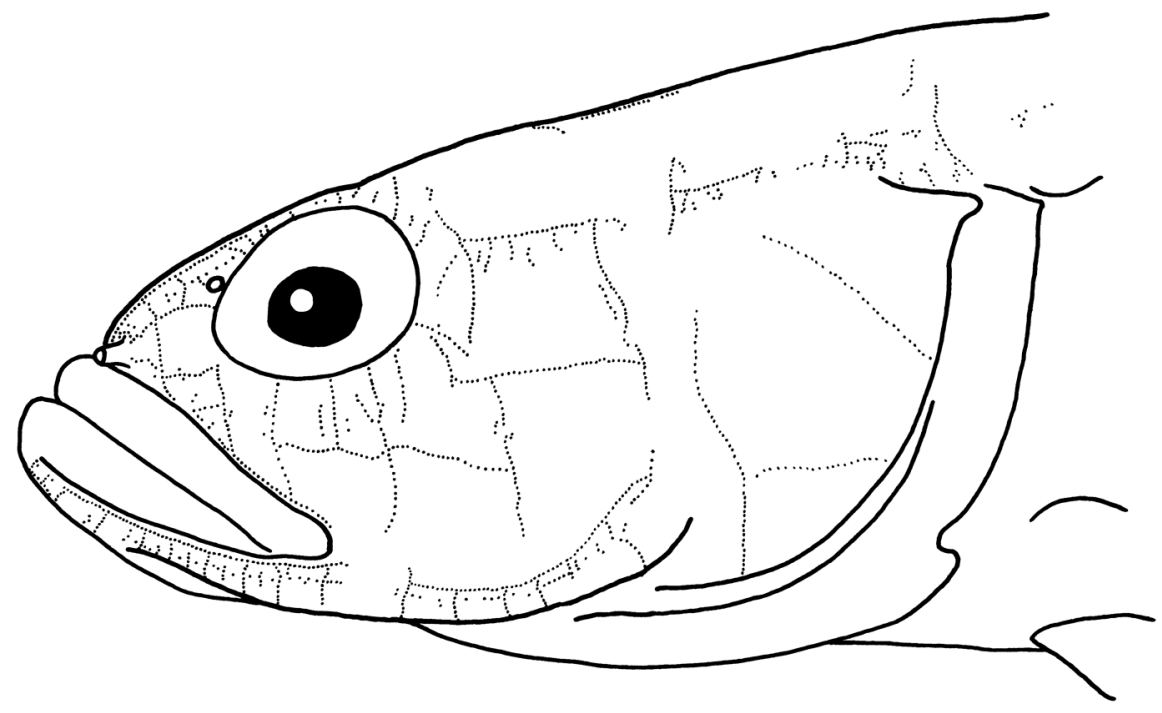

FIGURE 2. Head of Eleotris acanthopoma (URM-P 45009, $45.3 \mathrm{~mm}$ in standard length) showing arrangement of the cephalic sensory papillae.

distinct patterns; pectoral and pelvic fins uniformly pale grayish brown without distinct patterns; caudal fin translucent with eight to 10 dark brown transverse bars.

\section{Ecological Notes}

Eleotris acanthopoma was found together with juveniles of blacktail snapper, Lutjanus fulvus, in the vicinity of stones or wooden debris in shallow-water areas $(5-20 \mathrm{~cm}$ in water depth) with muddy bottoms near the shore in northwestern Moorea.

\section{Mitochondrial DNA Phylogeny}

A total of $995 \mathrm{bp}$ of the mitochondrial ND5 gene sequence was determined or cited from 34 specimens of four Eleotris species and two species of related genera. The 995 characters included no indels (insertion and/or deletion events) and were perfectly aligned. A neighbor-joining tree of nucleotide sequences (haplotypes) from Eleotris and related genera (Figure 3) clearly grouped the four E. acanthopoma specimens from Moorea into the same lineage as $E$. acanthopoma specimens from Japan and the Philippines. Two individuals from Moorea and one from the Philippines had identical nucleotide sequences.

\section{DISCUSSION}

Akihito (1967) examined the morphology of 72 Eleotris acanthopoma specimens mainly from southern Japan and Taiwan, as well as Bleeker's holotype from Sumatra. The morphology of E. acanthopoma collected in Moorea is identical to that described by Akihito (1967) for all of the characters examined, including the arrangements of the cephalic sensory papillae and meristic characters. It is therefore suggested that there is no difference in morphology between E. acanthopoma from Moorea and those from the Northwest Pacific.

Eleotris acanthopoma was described originally by Bleeker (1853) based on specimens from western Sumatra. Records of this species are not commonly known; however, this is likely due to E. acanthopoma being considered a junior synonym of the congeneric E. melanosoma until Akihito (1967) demonstrated that they are two independent species. Eleotris acanthopoma has been reported from southern Japan, including Honshu, Shikoku, Kyushu, the Ryukyu Archipelago, and the Ogasawara Islands (Akihito 1967, Nakabo 2002); Taiwan (Akihito 1967); Hong Kong (Ni and Kwok 1999); Cebu, Philippines (this study); Lombok, Indonesia (Harada and Suharti 2000); 


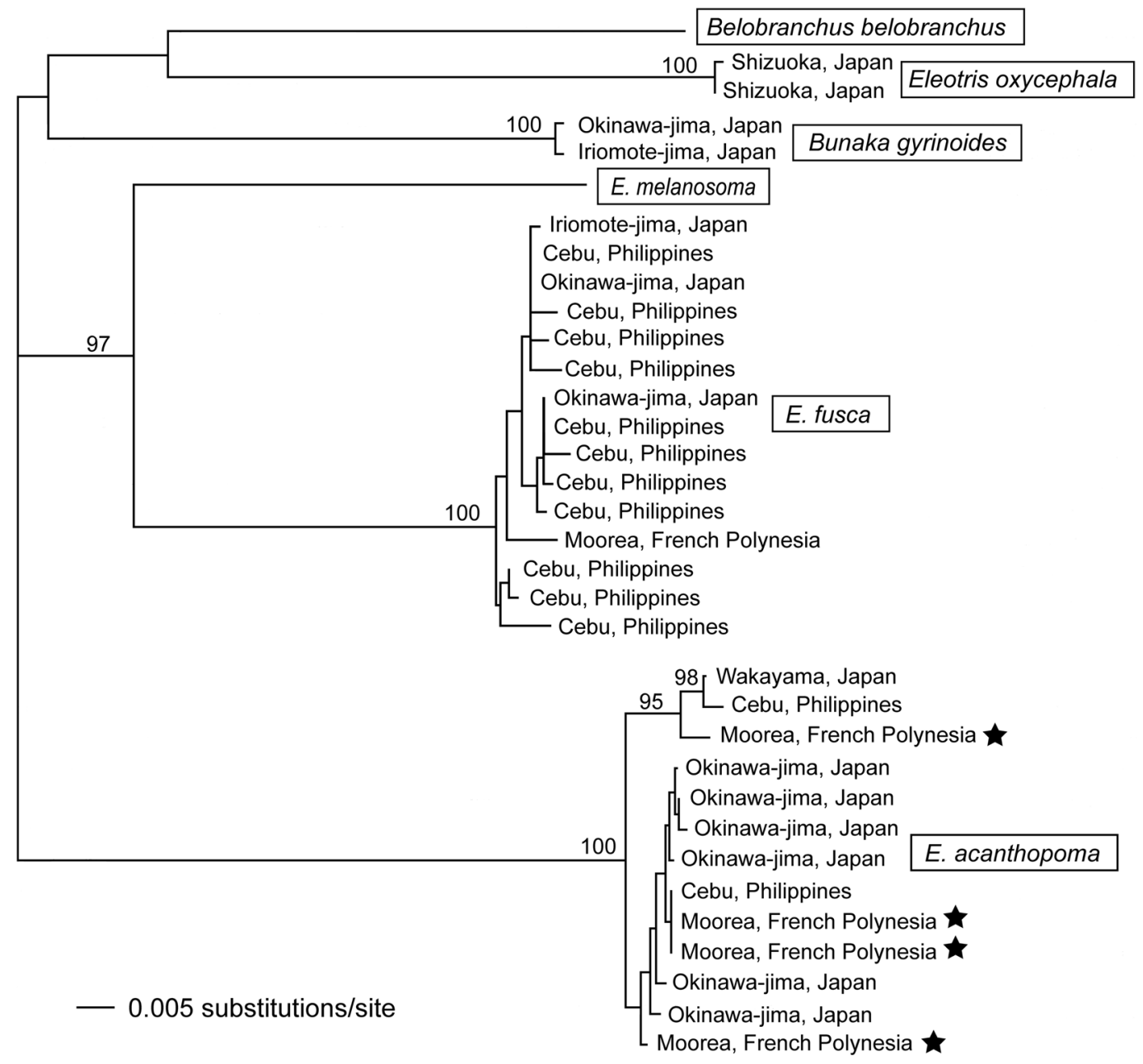

FIgURE 3. Neighbor-joining tree based on genetic distances estimated from partial mitochondrial NADH dehydrogenase subunit 5 (ND5) gene sequences $(995 \mathrm{bp})$ of four Eleotris species including French Polynesian samples and two related genera. Distances were based on Kimura's two-parameter model. Numbers adjacent to internal branches indicate bootstrap probabilities (>90\%) based on 1,000 pseudoreplicates. Solid stars represent E. acanthopoma from French Polynesia.

the Mariana Islands (Donaldson and Myers 2002); northeastern Australia (Allen et al. 2002); the Solomon Islands (Blaber and Milton 1990); New Caledonia (Marquet et al. 2003), and Moorea (this study) (Figure 4). Because Moorea is located approximately 4,500 $\mathrm{km}$ from New Caledonia, the closest previously known locality of E. acanthopoma, this discovery markedly extends the known range of this species.

These findings therefore suggest that $E$. acanthopoma has a range that is considerably larger than was previously thought, extending from the subtropical Northwest Pacific to the east-central tropical South Pacific. Maeda et al. $(2007,2008)$ indicated that E. acanthopoma larvae have a considerable capacity for dispersal. The mitochondrial DNA phylogeny presented here suggests that the panmictic $E$. acanthopoma populations in the tropical Pacific Ocean are widely distributed by the North and South Equatorial Currents and the Equatorial Counter Current during the pelagic larval stage. 


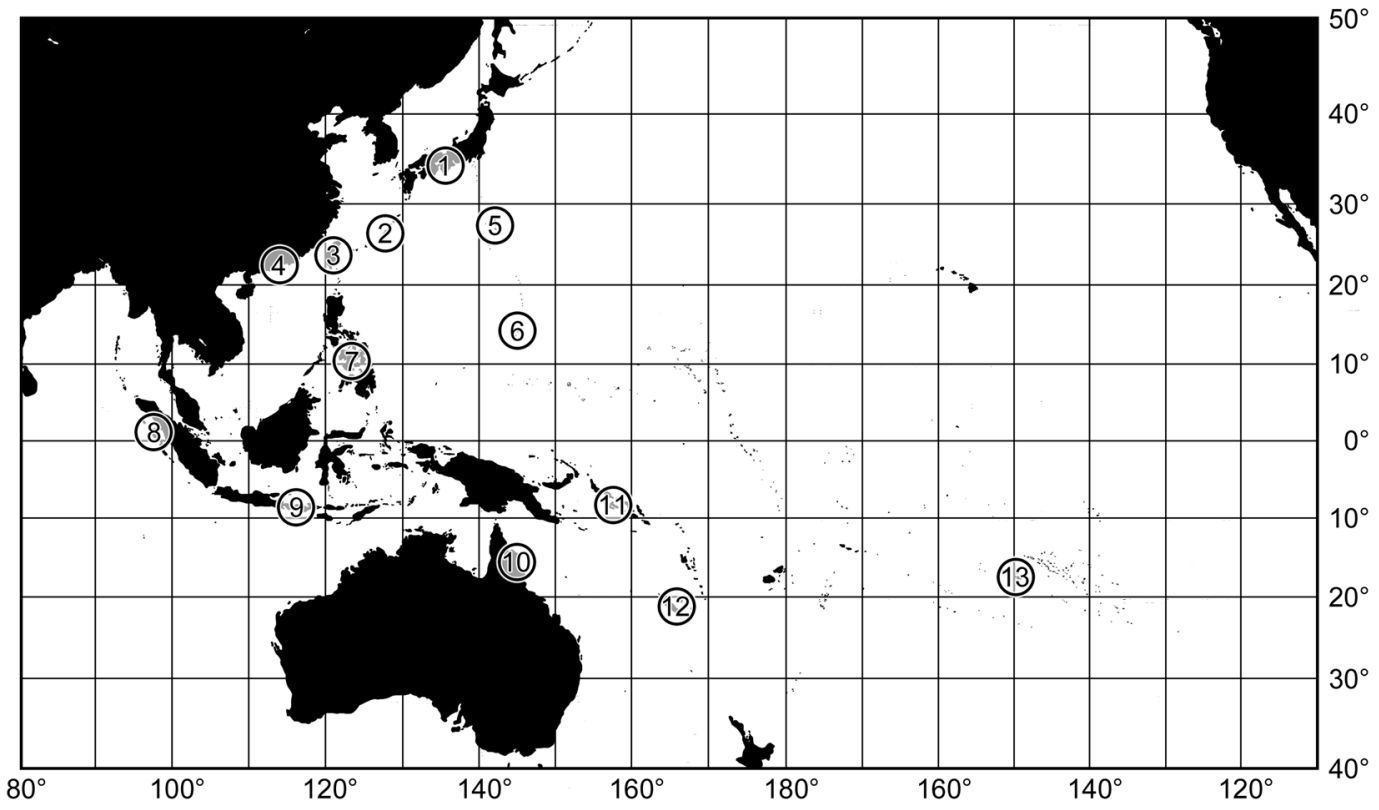

FIgURE 4. Geographical distribution of Eleotris acanthopoma: 1, Honshu, Shikoku, and Kyushu; 2, Ryukyu Archipelago; 3, Taiwan; 4, Hong Kong; 5, Ogasawara Islands; 6, Mariana Islands; 7, Cebu; 8, western Sumatra; 9, Lombok; 10, northeastern Australia; 11, Solomon Islands; 12, New Caledonia; 13, Moorea.

\section{ACKNOWLEDGMENTS}

We thank M. Tsuchiya, H. Ota, A. Hagihara, and all staff members of the 21st Century COE program at the University of the Ryukyus for providing K.M. with the opportunity to collect the specimens used in this study. We are grateful to all of the members at the Richard B. Gump South Pacific Research Station of the University of California, Berkeley, French Polynesia (GUMP) and Centre de Recherches Insulaires et Observatoire de l'Environment, French Polynesia (CRIOBE) for their kind hospitality during our stay in French Polynesia and for supporting our study.

\section{Literature Cited}

Akihito, P. 1967. On four species of the gobiid fishes of the genus Eleotris found in Japan. Jpn. J. Ichthyol. 14:135-166.

. 1984. Gobioidei. Pages 228-229 in H. Masuda, K. Amaoka, C. Araga, T. Ueno, and T. Yoshino, eds. The fishes of
Japanese Archipelago. Tokai University Press, Tokyo.

Allen, G. R., S. H. Midgley, and M. Allen. 2002. Field guide to the freshwater fishes of Australia. CSIRO Publishing, Collingwood, Australia.

Bell, K. N. I., P. Pepin, and J. A. Brown. 1995. Seasonal, inverse cycling of length- and age-at-recruitment in the diadromous gobies Sicydium punctatum and Sicydium antillarum in Dominica, West Indies. Can. J. Fish. Aquat. Sci. 52:1535-1545.

Blaber, S. J. M., and D. A. Milton. 1990. Species composition, community structure and zoogeography of fishes of mangrove estuaries in the Solomon Islands. Mar. Biol. (Berl.) 105:259-267.

Bleeker, P. 1853. Diagnostische beschrijvingen van nieuwe of weinig bekende vischsoorten van Sumatra. Tiental V-X. Nat. Tijdschr. Ned. Ind. 4:243-302.

Donaldson, T. J., and R. Myers. 2002. Insular freshwater fish faunas of Micronesia: Patterns of species richness and similarity. Environ. Biol. Fishes 65:139-149. 
Dotsu, Y., K. Miyawaki, T. Matsuo, Y. Ono, and H. Takahashi. 2004. Induced spawning, larval rearing and development of the sleeper, Eleotris oxycephala Temminck et Schlegel, gobioid fish. Bull. Fac. Fish. Nagasaki Univ. 85:1-8.

Englund, R. A. 2003. Report for the $2002 \mathrm{~Pa}$ cific biological survey, Bishop Museum Austral Islands, French Polynesia Expedition to Raivavae and Rapa Iti. Bishop $\mathrm{Mu}-$ seum, Honolulu.

- 2004. Report for the 2003 Pacific biological survey, Bishop Museum Austral Islands, French Polynesia Expedition to Tubuai and Rurutu. Bishop Museum, Honolulu.

Fowler, H. W. 1932. Fresh-water fishes from the Marquesas and Society Islands. Occas. Pap. Bernice Pauahi Bishop Mus. 4:311.

Harada, S., and S. R. Suharti. 2000. Eleotrididae. Pages 350-351 in K. Matsuura, K. Sumadhiharga, and K. Tsukamoto, eds. Field guide to Lombok Island: Identification guide to marine organisms in seagrass beds of Lombok Island, Indonesia. Ocean Research Institute, University of Tokyo, Tokyo.

Herre, A. W. 1931. A list of fishes collected at Moorea, one of the Society Islands, being the first record from this island. J. Pan-Pac. Res. Inst. 6:10.

- 1932. A check list of fishes recorded from Tahiti. J. Pan-Pac. Res. Inst. 7:26.

Lindstrom, D. P. 1999. Molecular species identification of newly hatched Hawaiian amphidromous gobioid larvae. Mar. Biotechnol. 1:167-174.

Maeda, K., and K. Tachihara. 2005. Recruitment of amphidromous sleepers Eleotris acanthopoma, Eleotris melanosoma and Eleotris fusca into the Teima River, Okinawa Island. Ichthyol. Res. 52:325-335.

Maeda, K., N. Yamasaki, M. Kondo, and K. Tachihara. 2008. Reproductive biology and early development of two species of sleeper, Eleotris acanthopoma and Eleotris fusca (Teleostei: Eleotridae). Pac. Sci. 62:327-340.
Maeda, K., N. Yamasaki, and K. Tachihara. 2007. Size and age at recruitment and spawning season of sleeper, genus Eleotris (Teleostei: Eleotridae), on Okinawa Island, southern Japan. Raffles Bull. Zool. Suppl. 14:199-207.

Marquet, G., and R. Galzin. 1992. Systématique, répartition et biomasse des poissons d'eau douce de Polynésie Française. Cybium 16:245-259.

Marquet, G., P. Keith, and E. Vigneux. 2003. Atlas des poissons et des crustacés d'eau douce de Nouvelle-Calédonie. Publications Scientifiques du Muséum National D'Histoire Naturelle, Paris.

Miya, M., H. Takeshima, H. Endo, N. B. Ishiguro, J. G. Inoue, T. Mukai, T. P. Satoh, M. Yamaguchi, A. Kawaguchi, K. Mabuchi, S. M. Shirai, and M. Nishida. 2003. Major patterns of higher teleostean phylogenies: A new perspective based on 100 complete mitochondrial DNA sequences. Mol. Phylogenet. Evol. 26:121138.

Mukai, T., S. Nakamura, T. Suzuki, and M. Nishida. 2005. Mitochondrial DNA divergence in yoshinobori gobies (Rhinogobius species complex) between the Bonin Islands and the Japan-Ryukyu Archipelago. Ichthyol. Res. 52:410-413.

Nakabo, T. 2002. Fishes of Japan with pictorial keys to the species. English ed. Tokai University Press, Tokyo.

Ni, I.-H., and K.-Y. Kwok. 1999. Marine fish fauna in Hong Kong waters. Zool. Stud. 38:130-152.

Pezold, F., and B. Cage. 2002. A review of the spinycheek sleepers, genus Eleotris (Teleostei: Eleotridae), of the Western Hemisphere, with comparison to the West African species. Tulane Stud. Zool. Bot. 31:19-63.

Pusey, B., M. Kennard, and A. Arthington. 2004. Freshwater fishes of north-eastern Australia. CSIRO Publishing, Collingwood, Australia.

Resh, V. H., M. Moser, and M. Poole. 1999. Feeding habits of some freshwater fishes in streams of Moorea, French Polynesia. Ann. Limnol. 35:205-210. 


\section{Appendix}

Samples for DNA Analysis

\begin{tabular}{|c|c|c|c|}
\hline Species & Locality & $\begin{array}{c}\text { Catalog No. of } \\
\text { Voucher Specimen }\end{array}$ & Acc. No. \\
\hline Belobranchus belobranchus & Danao, Cebu, Philippines & URM-P 45064 & AB499299 \\
\hline \multirow[t]{2}{*}{ Bunaka gyrinoides } & Teima, Okinawa-jima, Japan & URM-P 45134 & AB544426 \\
\hline & Uehara, Iriomote-jima, Japan & No voucher & AB499300 \\
\hline \multirow[t]{2}{*}{ Eleotris oxycephala } & Yoshida, Shizuoka, Japan & No voucher & AB499301 \\
\hline & Shizuoka, Shizuoka, Japan & KPM-NI 25014 & AB544427 \\
\hline Eleotris melanosoma & Taiho, Okinawa-jima, Japan & KPM-NI 23490 & AB499302 \\
\hline \multirow[t]{15}{*}{ Eleotris fusca } & Uehara, Iriomote-jima, Japan & No voucher & AB499303 \\
\hline & Yona, Okinawa-jima, Japan & URM-P 45150 & AB544428 \\
\hline & Yona, Okinawa-jima, Japan & URM-P 45631 & AB544429 \\
\hline & Panalipan, Cebu, Philippines & URM-P 45051 & AB544430 \\
\hline & Panalipan, Cebu, Philippines & URM-P 45052 & AB544431 \\
\hline & Panalipan, Cebu, Philippines & URM-P 45053 & AB544432 \\
\hline & Panalipan, Cebu, Philippines & URM-P 45054 & AB544429 \\
\hline & Panalipan, Cebu, Philippines & URM-P 45055 & AB544433 \\
\hline & Panalipan, Cebu, Philippines & URM-P 45056 & AB544434 \\
\hline & Panalipan, Cebu, Philippines & URM-P 45057 & AB544428 \\
\hline & Panalipan, Cebu, Philippines & URM-P 45058 & AB544435 \\
\hline & Panalipan, Cebu, Philippines & URM-P 45059 & AB544436 \\
\hline & Panalipan, Cebu, Philippines & URM-P 45060 & AB544437 \\
\hline & Danao, Cebu, Philippines & URM-P 45062 & AB544438 \\
\hline & Moorea, French Polynesia & URM-P 45014 & AB499304 \\
\hline \multirow{13}{*}{ Eleotris acanthopoma } & Kirime, Wakayama, Japan & No voucher & AP004455 \\
\hline & Aritsu, Okinawa-jima, Japan & No voucher & AB499305 \\
\hline & Yona, Okinawa-jima, Japan & URM-P 45632 & AB544439 \\
\hline & Yona, Okinawa-jima, Japan & URM-P 45633 & AB544440 \\
\hline & Yona, Okinawa-jima, Japan & URM-P 45634 & AB544441 \\
\hline & Yona, Okinawa-jima, Japan & URM-P 45635 & AB544442 \\
\hline & Yona, Okinawa-jima, Japan & URM-P 45636 & AB544443 \\
\hline & Dalaguete, Cebu, Philippines & URM-P 45047 & AB499306 \\
\hline & Dalaguete, Cebu, Philippines & URM-P 45049 & AB499307 \\
\hline & Moorea, French Polynesia & URM-P 45010 & AB499307 \\
\hline & Moorea, French Polynesia & URM-P 45011 & AB499308 \\
\hline & Moorea, French Polynesia & URM-P 45012 & AB499307 \\
\hline & Moorea, French Polynesia & URM-P 45013 & AB499309 \\
\hline
\end{tabular}

